\title{
Potensi Mikrob Asal Air Rendaman Limbah Jamur Tiram untuk Menghambat Alternaria solani Sorr. in Vitro dan Penyakit Bercak Cokelat pada Tomat
}

\author{
Noor Istifadah", Santa Monica, Fitri Widiantini, dan Sri Hartati \\ Program Studi Agroteknologi, Fakultas Pertanian, Universitas Padjadjaran \\ Jl. Raya Bandung-Sumedang KM 21, Jatinangor, Indonesia 45363 \\ *Alamat korespondensi: n.istifadah@unpad.ac.id
}

\begin{abstract}
The potential of microbes isolated from water extract of spent substrate of oyster mushroom to inhibit Alternaria solani Sorr. In vitro and early blight disease of tomato
\end{abstract}

Early blight (Alternaria solani Sorr.) is an important disease of tomato. One of the environmentallyfriendly control methods is biological control. Spent mushroom substrates are potential sources of antagonistic microbes for biological control of plant diseases. The objectives of this study were to isolate microbes from the water extract of spent substrate of oyster mushroom and examine their abilities to inhibit the growth of $A$. solani in vitro and suppress the pathogen infection in tomato fruits and plants. The experiments were conducted in several steps which were isolation, selection and in vitro test on the microbes' abilities to inhibit the growth of $A$. solani using dual culture method. The selected isolates were examined their potential as pathogen in tomato fruit and the non pathogenic isolates capable of inhibiting $A$. solani infection in tomato fruit was further tested in tomato plants. The results showed that among 23 microbial isolates from the water extract of spent substrate of oyster mushroom, there were eight isolates that inhibited $A$. solani growth with inhibition level ranging from $70.1 \%$ to $81.2 \%$. In tomato fruits, two fungal isolates (Rhizopus spp.) were pathogenic, whereas three non pathogenic isolates inhibited $A$ solani infection in tomato fruits by $78.4 \%$ and $83.7 \%$. In tomato plants, two isolates (fungal isolate TJ4 and bacterial isolate TB25) suppressed early blight disease by $54.8 \%$ and $37.9 \%$ respectively.

Keywords: Bacterial isolates, Fungal isolates, Pleurotus, Tomato fruit

\begin{abstract}
ABSTRAK
Penyakit bercak cokelat yang disebabkan oleh Alternaria solani Sorr. merupakan salah satu penyakit penting pada tanaman tomat. Salah satu cara pengendalian yang ramah lingkungan adalah pengendalian biologi. Bahan organik termasuk limbah jamur tiram merupakan salah satu sumber yang potensial untuk mendapatkan mikrob yang bersifat antagonistik terhadap patogen tanaman. Penelitian ini bertujuan untuk mendapatkan mikrob dari air rendaman limbah jamur tiram yang dapat menghambat pertumbuhan Alternaria solani secara in vitro dan menekan penyakit bercak cokelat pada buah dan daun tomat. Percobaan terdiri dari beberapa tahap antara lain isolasi mikrob dari air rendaman limbah jamur tiram, seleksi awal dan uji lanjutan kemampuan isolat mikrob untuk menghambat pertumbuhan $A$. solani secara in vitro dengan metode dual culture. Isolat hasil seleksi in vitro diuji kemungkinan patogensitasnya pada buah tomat dan isolat non patogenik yang dapat menghambat infeksi $A$. solani diuji lebih lanjut pada tanaman tomat. Hasil percobaan menunjukkan bahwa di antara 23 isolat mikrob yang diperoleh dari air rendaman limbah jamur tiram terdapat delapan isolat yang dapat menghambat pertumbuhan $A$. solani secara in vitro dengan tingkat penghambatan berkisar antara 70,1\% sampai $81,2 \%$. Pada pengujian di buah tomat, dua isolat jamur berhifa (Rhizopus spp.) bersifat patogenik dan tiga isolat mikrob non patogenik dapat menghambat infeksi $A$ solani pada buah tomat sebesar $78,4 \%$ dan $83,7 \%$. Pada percobaan di tanaman tomat, hanya
\end{abstract}


dua isolat (isolat jamur TJ4 dan isolat bakteri TB25) yang dapat menekan penyakit bercak cokelat masing-masing sebesar $54,8 \%$ dan $37,9 \%$.

Kata Kunci: Bakteri, Buah tomat, Jamur, Khamir, Pleurotus

\section{PENDAHULUAN}

Tomat merupakan salah satu produk hortikultura yang banyak dibutuhkan oleh masyarakat baik sebagai sayuran, buah atau untuk bahan baku industri. Salah satu kendala dalam budidaya tomat adalah adanya penyakit bercak cokelat yang disebabkan oleh jamur Alternaria solani Sorr. Infeksi patogen ini dapat terjadi pada berbagai bagian tanaman di atas tanah seperti daun, batang, tangkai dan juga buah. Penyakit ini menyebabkan penurunan kuantitas dan kualitas buah tomat (Adhikari et al., 2017) dan dapat menyebabkan kerugian sampai 79\% (Chaerani \& Voorrips, 2006).

Cara pengendalian yang sering dilakukan adalah dengan penyemprotan menggunakan fungisida. Penggunaan fungisida yang terus menerus dan kurang bijaksana dapat menimbulkan dampak negatif seperti terjadinya resistensi patogen dan akumulasi residu pada produk maupun pencemaran lingkungan (Mahmood et al., 2014). Oleh karena itu, perlu dikembangkan cara pengendalian yang ramah lingkungan diantaranya adalah pengendalian secara biologi.

Salah satu sumber mikrob yang dapat digunakan untuk pengendalian penyakit tanaman adalah bahan organik. Di Indonesia, bahan organik yang belum banyak dikaji potensi mikrobnya adalah limbah media tanam jamur tiram (Pleurotus spp.). Selama ini, pemanfaatan limbah jamur tiram masih belum optimal. Limbah ini pada umumnya hanya dimanfaatkan sebagai bahan campuran untuk pembuatan kompos.

Limbah jamur konsumsi merupakan bahan organik yang sangat berpotensi untuk menekan penyakit tanaman (Rinker, 2017). Kemampuan limbah jamur tiram untuk menekan penyakit tanaman telah dilaporkan. Aplikasi limbah media jamur tiram pada medium tanam dapat menekan pembentukan gall dan populasi juvenile-2 nematoda Meloidogyne spp. pada tanaman tomat (Aslam \& Saifullah, 2013). Aplikasi limbah jamur tiram pada medium persemaian juga dapat mengendalikan penyakit rebah semai (Rhizoctonia solani) pada tanaman tomat dengan tingkat penekanan sampai 100\% (Herawati \& Istifadah, 2018). Yusidah \&
Istifadah (2018) juga melaporkan bahwa aplikasi limbah media tanam jamur tiram pada lubang tanam serta penyiraman dengan air rendamannya dapat menekan penyakit moler (Fusarium oxysporum f.sp cepae) pada tanaman bawang merah sebesar $43,7 \%$ $76,3 \%$ serta mendukung pertumbuhan tanaman bawang merah.

Kemampuan limbah media jamur ataupun air rendamannya dalam menekan penyakit tanaman pada umumnya karena adanya mikrob yang bersifat antagonistik terhadap patogen (Herawati \& Istifadah, 2018; Adedeji \& Aduramigba, 2016; Seephueak et al., 2017). Beberapa mikrob yang berasal dari limbah jamur tiram dilaporkan dapat menghambat patogen atau penyakit tanaman. Viji et al. (2003) menemukan tiga isolat Pseudomonas aeruginosa yang dapat menghambat pertumbuhan Pyricularia grisea secara in vitro dan menekan perkembangan penyakit bercak kelabu pada tanaman Lolium perenne. Adedeji \& Aduramigba (2016) melaporkan bahwa isolat-isolat jamur dari limbah jamur tiram dapat menghambat pertumbuhan Fusarium oxysporum f.sp. lycopersici. Zulfikar et al. (2018) juga menemukan bakteri dari limbah media tanam jamur tiram yang merupakan genus Bacillus dapat menghambat pertumbuhan Fusarium solani secara in vitro dan menekan kejadian penyakit rebah semai pada tanaman tomat.

Penghambatan patogen oleh mikrob antagonis dapat terjadi melalui beberapa mekanisme. Mikrob antagonis dapat berkompetisi dengan patogen dalam mendapatkan tempat hidup dan nutrisi, menghasilkan senyawa yang bersifat antimikrob serta memarasit patogen atau dikenal dengan mekanisme hiperparasitisme (Köhl et al., 2019). Penelitian ini bertujuan untuk mengisolasi dan menguji mikrob yang berasal dari air rendaman limbah jamur tiram untuk menghambat pertumbuhan jamur $A$. solani secara in vitro dan menekan infeksi patogen tersebut pada buah dan tanaman tomat.

\section{BAHAN DAN METODE}

\section{Isolasi Mikrob Air Rendaman Limbah Media Jamur}

Limbah jamur tiram yang digunakan diperoleh dari produsen jamur konsumsi (IP Farm) 
di Cikole, Lembang, Bandung Barat. Air rendaman limbah jamur dibuat dengan cara limbah atau baglog bekas jamur tiram yang telah dipotong-potong dicampur dengan air (1:4, v/v) dan diinkubasikan dalam wadah tertutup selama 10 hari. Isolasi mikrob dilakukan dengan metode serial dilution dan pour plate method (Dhingra \& Sinclair, 1995). Untuk mendapatkan berbagai jenis mikrob, maka isolasi mikrob dilakukan menggunakan beberapa media yaitu Nutrient Agar (8 g Nutrient broth, $20 \mathrm{~g}$ agar, dan 1 L air), Malt Extract Agar (30 g malt ekstrak, 3 g pepton, $20 \mathrm{~g}$ agar, dan $1 \mathrm{~L}$ air), media International Streptomyces Project 2 (4 g yeast extract, $4 \mathrm{~g}$ dextrose, $10 \mathrm{gr}$ malt extraxt, $20 \mathrm{~g}$ agar, dan $1 \mathrm{~L}$ air), serta Potato Dextrose Agar/PDA (200 g kentang, 20 $\mathrm{g}$ dextrose, $20 \mathrm{~g}$ agar, dan $1 \mathrm{~L}$ air) yang diberi antibiotic chloramphenicol (0,05\%). Medium PDA ini lebih ditujukan untuk mengisolasi mikrob yang berupa jamur.

\section{Uji Antagonisme Isolat Mikrob secara in Vitro}

Semua isolat yang diperoleh dari air rendaman limbah jamur tiram diuji kemampuannya untuk menghambat jamur $A$. solani secara in vitro. Pengujian dilakukan dengan metode dual culture pada medium half strength PDA. Biakan jamur patogen $A$. solani yang digunakan merupakan biakan yang digunakan pada penelitian sebelumnya (Istifadah dkk., 2020). Untuk keperluan penelitian ini, patogen tersebut dibiakkan kembali pada medium half strength PDA.

Potongan biakan A. solani (berdiameter 5 $\mathrm{mm}$ ) diletakkan berdampingan dengan isolat mikrob dengan jarak $3 \mathrm{~cm}$. Isolat jamur diuji dalam bentuk potongan biakan (berdiameter $5 \mathrm{~mm}$ ), sedangkan untuk isolat bakteri, suspensi bakteri digoreskan menggunakan cotton bud. Pada kontrol, biakan jamur patogen diletakkan berdampingan dengan potongan medium tanpa isolat mikrob. Isolat mikrob yang menunjukkan adanya zona hambat atau dapat menghambat pertumbuhan $A$. solani sebesar $>50 \%$ diuji kembali untuk mengonfirmasi kemampuannya dalam menghambat patogen.

Percoban pada uji secara in vitro lanjutan menggunakan Rancangan Acak Lengkap dengan perlakuan isolat mikrob terseleksi dan kontrol. Pengukuran jari-jari koloni patogen ke arah isolat mikrob yang diuji dilakukan setiap hari sampai koloni patogen pada kontrol hampir memenuhi medium dalam petridish.

\section{Uji Kemampuan Isolat Mikrob untuk Menghambat Infeksi $A$. solani pada Buah Tomat}

Percobaan pada buah tomat menggunakan Rancangan Acak Kelompok dengan perlakuan berupa isolat mikrob hasil seleksi in vitro dan kontrol. Masing-masing perlakuan diulang tiga kali dengan kotak tempat inkubasi tomat dianggap sebagai bloknya.

Buah tomat yang digunakan dibersihkan dengan air mengalir kemudian permukaannya didesinfeksi menggunakan alkohol 70\%. Inokulasi patogen dilakukan dengan menempelkan potongan biakan $A$. solani (diameter $5 \mathrm{~mm}$ ) yang telah ditumpukkan berhadapan dengan potongan biakan mikrob pada bagian buah tomat yang telah dilukai, lalu ditutup dengan selotape dan plastic wrap (Istifadah dkk., 2020). Cara ini dimaksudkan untuk mengoptimalkan kemampuan isolat untuk menghambat patogen sebelum masuk ke dalam jaringan yang telah diberi pelukaan.

Untuk perlakuan kontrol, potongan biakan patogen ditumpukkan dengan potongan medium PDA, kemudian diletakkan pada jaringan buah tomat yang telah dilukai. Buah yang telah diinokulasi kemudian dimasukkan ke dalam kotak plastik yang telah diberi kapas basah untuk menjaga kondisi dalam kotak selalu lembab. Selotape dan inokulum patogen dibuka ketika buah tomat pada kontrol sudah muncul gejala. Untuk menguji kemungkinan isolat mikrob bersifat patogenik, potongan biakan masing-masing mikrob juga diinokulasikan pada buah tomat dengan metoda yang sama dengan kontrol. Pengamatan terhadap diameter gejala dilakukan setiap hari sampai tujuh hari setelah inokulasi.

\section{Pengujian pada Tanaman Tomat}

Percobaan ini dimaksudkan untuk menguji isolat mikrob non patogenik hasil seleksi pada buah tomat untuk menekan penyakit bercak cokelat pada daun tomat. Pengujian dilakukan pada tanaman tomat berusia 1,5 bulan. Daun tomat disemprot dengan menggunakan suspensi inokulum mikrob yang diuji. Kerapatan inokulum untuk suspensi spora jamur adalah $10^{7} \mathrm{spora} / \mathrm{mL}$, sedangkan untuk bakteri adalah $10^{7} \mathrm{cfu} / \mathrm{mL}$.

Tanaman tomat yang telah diberi perlakuan mikrob kemudian kemudian disungkup dengan plastik selama 24 jam. Hal ini dimaksudkan untuk memberikan kesempatan mikrob antagonis berkembang pada daun. Setelah itu, anak daun majemuk yang paling ujung (paling lebar) 
diinokulasi dengan patogen. Pada perlakuan kontrol, daun disemprot dengan menggunakan air steril, sedangkan pada perlakuan pembanding daun disemprot menggunakan fungisida berbahan aktif mancoze $b$ sesuai dengan konsentrasi standar.

Mengingat $A$. solani adalah jamur yang sulit menghasilkan konidia pada media agar, maka patogen ini diinokulasikan dengan cara menempelkan potongan biakan patogen (diameter 8 $\mathrm{mm}$ ) pada bagian daun yang telah diberi pelukaan dengan ujung jarum steril. Potongan biakan dilekatkan pada jaringan daun dengan bantuan selotip dan plastic wrap. Tanaman tomat yang telah diinokulasi patogen ditutup menggunakan sungkup plastik selama 48 jam. Biakan patogen dilepas setelah gejala penyakit muncul pada kontrol (Istifadah \& Hakim, 2017).

Pengamatan dilakukan setiap hari (setelah inokulum patogen dilepas) dengan cara mengukur luas bercak dengan bantuan plastik mika dan program ImageJ. Data luas bercak yang diperoleh digunakan untuk menghitung Area Under the Disease Progress Curve/AUDPC (Madden et al., 2007).

\section{Analisis Data}

Data yang diperoleh dianalisis secara statistik dengan menggunakan software SPSS versi
20. Normalitas data dicek, sebelum dilakukan Analisis of Varians (ANOVA). Apabila terdapat perbedaan nyata antar perlakuan maka dilakukan uji lanjutan dengan Tukey's HSD pada taraf nyata 5\%.

\section{HASIL DAN PEMBAHASAN}

\section{Hasil Isolasi dan Seleksi Mikrob Asal Air Rendaman Limbah Jamur Tiram}

Hasil isolasi mikrob dari air rendaman limbah jamur tiram diperoleh 23 isolat yaitu empat isolat jamur yang membentuk hifa serta 19 isolat mikrob yang koloninya seperti bakteri. Pada tahap seleksi, sebagian besar isolat (15 isolat) menunjukkan penghambatan terhadap pertumbuhan $A$. solani dengan tingkat penghambatan kurang dari $50 \%$ atau hanya sebesar $24,1 \%-47,7 \%$. Hanya delapan isolat yang dapat menghambat pertumbuhan $A$. solani secara in vitro dengan kisaran penghambatan sebesar 57,8\% $86,1 \%$. Isolat yang menunjukkan tingkat penghambatan $>50 \%$ tersebut adalah empat isolat jamur, satu isolat khamir, dan tiga isolat bakteri (Gambar 1). Delapan isolat tersebut diuji lagi untuk mengonfirmasi kemampuan penghambatannya.

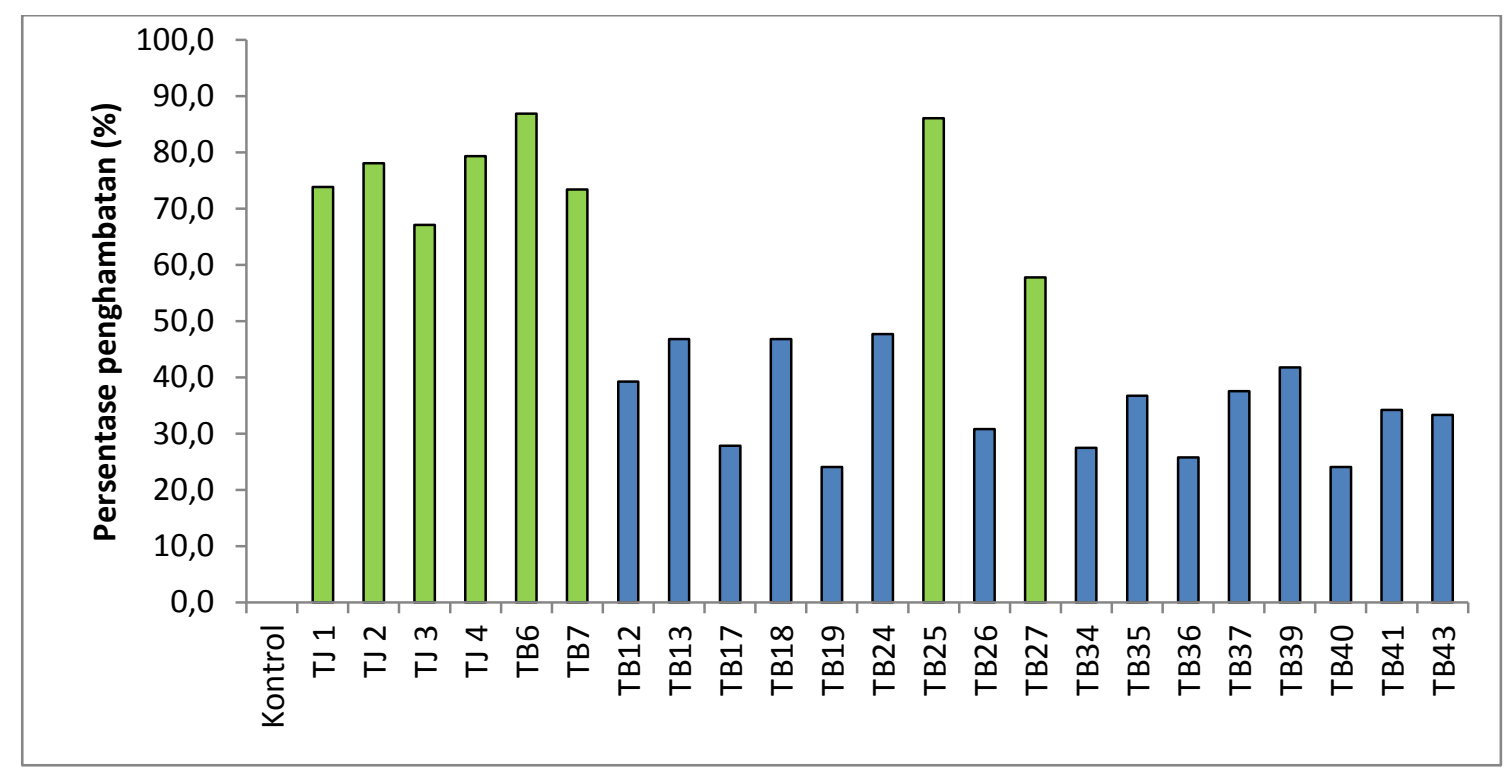

Gambar 1. Penghambatan pertumbuhan $A$. solani secara in vitro oleh mikrob yang diisolasi dari air rendaman limbah jamur tiram.

Hasil uji lanjutan menunjukkan bahwa delapan isolat hasil seleksi dapat menghambat pertumbuhan $A$. solani secara in vitro dengan tingkat penghambatan berkisar antara $70,1 \%$ sampai $81,2 \%$ (Tabel 1). Hasil ini mengonfirmasi 
kemampuan isolat-isolat tersebut pada tahap seleksi sebelumnya.

Interaksi yang terjadi antara mikrob antagonis dengan patogen pada dual culture, dapat digunakan untuk menduga mekanisme antagonisme yang terjadi. Pada isolat bakteri dan khamir, terdapat zona bening antara koloni mikrob yang diuji dengan koloni patogen. Hal ini mengindikasikan adanya mekanisme antibiosis yang mana mikrob yang diuji mengeluarkan metabolit sekunder yang dapat terdifusi ke dalam medium sehingga menghambat pertumbuhan patogen pada medium tersebut. Menurut Davis \& Stout (1971), berdasarkan lebarnya zona hambat yang terbentuk, potensi antibiosis suatu mikrob dapat dikelompokkan menjadi empat, yaitu sangat kuat apabila zona hambat $\geq 20 \mathrm{~mm}$; kuat apabila zona hambatnya $10-20 \mathrm{~mm}$; sedang apabila zona hambatnya 5-10 $\mathrm{mm}$; dan lemah apabila zona hambat $\leq 5 \mathrm{~mm}$. Di antara isolat bakteri dan khamir yang diuji, terdapat dua isolat memiliki potensi antibiosis lemah dan dua isolat mempunyai potensi antibiosis sedang. Zona hambat ini tidak terbentuk pada semua isolat jamur berhifa yang diuji (Tabel 1).

Tabel 1. Kemampuan isolat jamur asal air rendaman limbah media jamur untuk menghambat pertumbuhan A. solani secara in vitro (pada 10 hari setelah perlakuan)

\begin{tabular}{lcrccc}
\hline \multicolumn{1}{c}{$\begin{array}{c}\text { Isolat } \\
\text { jamur }\end{array}$} & Mikrob & $\begin{array}{c}\text { Jari-jari } \\
\text { patogen }(\mathrm{mm})\end{array}$ & $\begin{array}{c}\text { Penghambatan } \\
(\%)\end{array}$ & $\begin{array}{c}\text { Zona bening } \\
(\mathrm{mm})\end{array}$ & $\begin{array}{c}\text { Potensi } \\
\text { antibiosis }\end{array}$ \\
\hline Kontrol & & $43,5 \mathrm{e}$ & 0,0 & - & \\
Isolat TJ1 & Jamur berhifa & $10,3 \mathrm{abc}$ & 76,2 & 0,0 & Tidak ada \\
Isolat TJ2 & Jamur berhifa & $9,0 \mathrm{ab}$ & 79,3 & 0,0 & Tidak ada \\
Isolat TJ3 & Jamur berhifa & $13,0 \mathrm{bc}$ & 70,1 & 0,0 & Tidak ada \\
Isolat TJ4 & Jamur berhifa & $8,2 \mathrm{a}$ & 81,2 & 0,0 & Tidak ada \\
Isolat TB6 & Khamir & $14,5 \mathrm{c}$ & 66,7 & 2,0 & Lemah \\
Isolat TB7 & Bakteri & $9,2 \mathrm{ab}$ & 78,9 & 5,0 & Sedang \\
Isolat TB25 & Bakteri & $9,5 \mathrm{ab}$ & 78,2 & 8,0 & Sedang \\
Isolat TB27 & Bakteri & $20,3 \mathrm{~d}$ & 53,3 & 1,0 & Lemah \\
\hline Keterangan: Angka yang diikuti huruf yang sama pada satu kolom tidak berbeda nyata menurut uji lanjut Tukey HSD pada taraf nyata \\
\multicolumn{2}{c}{ 5\%. Potensi antibiosis didasarkan pada kriteria yang digunakan oleh Davis \& Stout (1971). } &
\end{tabular}

Pada dual culture isolat jamur dengan patogen, pertumbuhan koloni jamur yang diuji tampak lebih cepat daripada patogen sehingga koloninya mendominasi media bahkan sampai ada yang menutupi koloni $A$. solani. Pada kasus ini, penghambatan pertumbuhan patogen diduga dikarenakan adanya kompetisi dari isolat jamur yang diuji. Köhl et al. (2019) menyatakan bahwa pertumbuhan mikrob antagonis yang cepat dapat memanfaatkan nutrisi dan ruang lebih efisien sehingga dapat mengompetisi patogen dalam mendapatkan nutrisi dan ruang tumbuh.

Berdasarkan karakteristik koloni dan mikroskopis diketahui bahwa dua isolat jamur berhifa yaitu isolat TJ1 dan TJ2 merupakan jamur dari genus Rhizopus, sedangkan isolat jamur TJ3 termasuk genus Mucor. Pada penelitian lain, jamur dari genus Rhizopus dan Mucor juga ditemukan pada limbah media jamur tiram (Omokaro \& Ogechi, 2014; Wiafe-Kwagyan \& Odamtten, 2018). Namun demikian, sebenarnya genus jamur yang banyak ditemukan pada limbah jamur tiram adalah dari genus Aspergillus, Penicillium dan Trichoderma (Adededi \& Aduramigba, 2016; Seephueak et al., 2017). Pada penelitian ini, empat isolat jamur berhifa yang terisolasi tidak ada satu pun yang termasuk ke dalam genus-genus jamur tersebut. Kurangnya variabilitas jenis jamur yang diperoleh pada limbah jamur tiram pada penelitian ini, kemungkinan karena limbah jamur yang digunakan adalah limbah yang baru beberapa hari dibuang setelah selesai masa panen sehingga belum banyak terkolonisasi oleh berbagai jenis jamur. Selain itu, adanya isolat jamur Rhizopus dan Mucor yang pertumbuhannya sangat cepat dan mendominasi medium kemungkinan juga menghambat pertumbuhan atau menutupi koloni jamur-jamur jenis lain.

\section{Kemampuan Isolat Mikrob dalam Menghambat Infeksi $A$. solani pada Buah Tomat}

Isolat-isolat hasil seleksi pada pengujian in vitro diuji kemampuannya untuk menghambat infeksi $A$. solani pada buah tomat. Hasil pengujian 
menunjukkan bahwa di antara isolat yang diuji, terdapat tiga isolat (isolat TJ4, TB6, dan TB 25) yang dapat menghambat infeksi $A$. solani pada buah tomat dengan tingkat penghambatan $>70 \%$ (Tabel 2). Pada perlakuan ini, bagian tomat yang dilukai terlihat mengering tanpa adanya perkembangan gejala lebih lanjut (Gambar 2B). Pada pengujian di buah tomat juga dilakukan uji patogensitas isolatisolat mikrob hasil seleksi in vitro. Di antara delapan isolat yang diuji, ternyata dua isolat jamur berhifa dapat menyebabkan pembusukan pada buah tomat atau bersifat patogenik (Tabel 2).

Pada pengujian di buah tomat, diketahui bahwa isolat jamur TJ1 dan TJ2 yang merupakan jamur dari genus Rhizophus ternyata bersifat patogenik. Walaupun ketika diinokulasikan bersamaan dengan patogen isolat ini sampai lima hari setelah perlakuan dapat menghambat terjadinya infeksi pada buah tomat sebesar 13\% - 35\%, namun pada tujuh hari setelah inokulasi isolat jamur ini mulai mengolonisasi bagian buah yang dilukai dan akhirnya buah menjadi busuk. Ketika diinokulasikan sendiri tanpa $A$. solani, pada hari kelima isolat-isolat jamur tersebut menyebabkan pembusukan pada bagian jaringan buah yang telah dilukai (Gambar 2C). Genus Rhizopus memang dikenal dapat bersifat parasit fakultatif atau saprofit yang dapat menjadi parasit pada buah dan sayuran terutama apabila lingkungan mendukung seperti terjadi pelukaan pada jaringan tanaman dan kelembaban yang tinggi (Singh \& Sharma, 2018). Kwon et al. (2001) melaporkan bahwa Rhizopus stolonifera dapat menyebabkan busuk basah pada tomat ceri.

Tabel 2. Diameter gejala dan persentase penekanan penyakit bercak cokelat di buah tomat pada berbagai perlakuan yang diamati tujuh hari setelah inokulasi patogen

\begin{tabular}{lcrccc}
\hline Perlakuan & Mikrob & $\begin{array}{r}\text { Diameter Gejala } \\
(\mathrm{mm})\end{array}$ & $\begin{array}{c}\text { Penekanan } \\
\text { Penyakit }(\%)\end{array}$ & Patogenesitas \\
\hline Kontrol & - & $12,3 \quad \mathrm{c}$ & 0,0 & - \\
Isolat TJ1 & Jamur berhifa & $10,7 \quad$ bc & 13,3 & Patogenik \\
Isolat TJ2 & Jamur berhifa & $8,0 \quad \mathrm{~b}$ & 35,0 & Patogenik \\
Isolat TJ3 & Jamur berhifa & $8,3 \quad$ bc & 32,2 & Non Patogenik \\
Isolat TJ4 & Jamur berhifa & $2,7 \quad \mathrm{a}$ & 78,4 & Non patogenik \\
Isolat TB6 & Khamir & $2,0 \mathrm{a}$ & 83,7 & Non-patogenik \\
Isolat TB7 & Bakteri & $10,0 \mathrm{bc}$ & 18,7 & Non-patogenik \\
Isolat TB25 & Bakteri & $2,7 \quad$ a & 78,4 & Non patogenik \\
Isolat TB27 & Bakteri & $8,7 \quad$ bc & 29,5 & Non-patogenik \\
\hline
\end{tabular}

Keterangan: Angka yang diikuti oleh huruf yang sama menunjukkan perlakuan yang tidak berbeda nyata pada taraf $5 \%$ menurut uji Tuckey HSD.
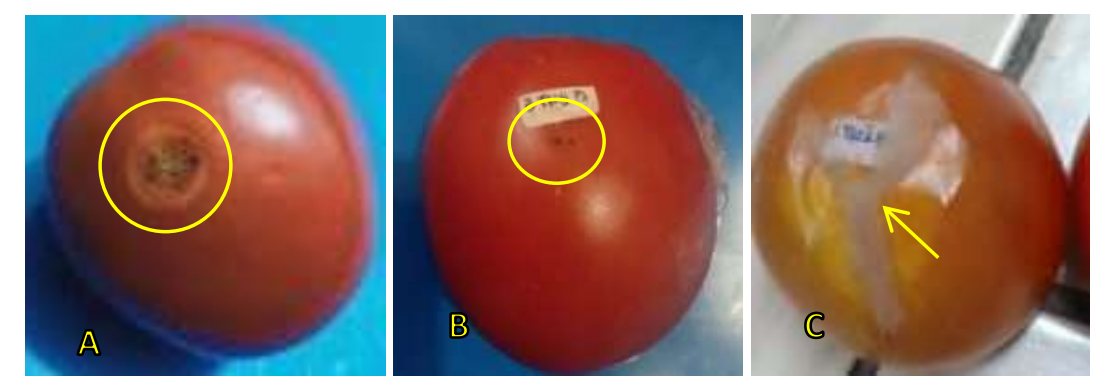

Gambar 2. Gejala penyakit karena A. solani di buah tomat pada 7 HSI. (A) Kontrol. (B) Perlakuan dengan patogen + isolat TB6. (C) Perlakuan dengan isolat jamur TJ2.

Berbeda dengan isolat jamur yang beberapa bersifat patogenik, isolat-isolat bakteri dan khamir asal limbah jamur tiram yang diuji pada buah tomat tidak ada yang menyebabkan penyakit atau bersifat patogenik. Buah tomat yang diinokulasi dengan isolat-isolat tersebut tetap tidak bergejala walaupun pada jaringan yang telah dilukai. Isolat-isolat yang bersifat patogenik dan juga isolat yang kurang efektif dalam pengujian pada buah tomat ini tidak digunakan pada percobaan pada tanaman tomat. 
Kemampuan Isolat Mikrob untuk Menekan Penyakit Bercak Cokelat pada Tanaman Tomat

Pada percobaan ini, gejala penyakit bercak cokelat pada kontrol terlihat jelas pada lima hari setelah inokulasi (HSI). Gejala yang terlihat berupa timbulnya bercak cokelat (nekrosis) disertai perubahan warna daun menjadi kekuningan atau khlorosis di sekitar bercak yang terbentuk. Kemunculan gejala penyakit bercak cokelat untuk pertama kali (masa inkubasi) pada perlakuan dengan isolat jamur TJ4 dan isolat bakteri TB25 baru mulai terlihat 6 - 7 HSI. Pada perlakuan kedua isolat tersebut, perkembangan gejala penyakit pada tanaman tomat tampak terhambat dan gejala nekrosisnya juga tidak kelilingi oleh jaringan berwarna kuning atau khlorosis (Gambar 3). Isolat jamur TJ4 dan isolat bakteri TB25 juga dapat menghambat intensitas penyakit bercak cokelat pada daun tomat masing-masing sebesar $54,8 \%$ dan $37,9 \%$ (Tabel 3).
Kemampuan mikrob antagonis dalam menekan suatu penyakit dapat melalui beberapa mekanisme. Isolat jamur TJ4 merupakan isolat yang pertumbuhannya cepat dan dapat meluas sehingga diduga penekanan penyakit terjadi karena jamur tersebut dapat mengompetisi patogen. Isolat bakteri TB25 merupakan isolat yang miliki potensi antibiosis walaupun kategorinya sedang sehingga kemungkinan penekanan penyakit dapat karena adanya produksi metabolit sekunder yang dapat menghambat patogen. Selain kompetisi dan antibiosis, penghambatan penyakit pada tanaman oleh mikrob antagonis dapat dikarenakan kemampuan mikrob tersebut untuk meningkatkan ketahanan tanaman terhadap penyakit (Köhl et al., 2019). Istifadah \& Herawati (2020) menemukan beberapa isolat bakteri yang berasal dari air rendaman limbah jamur tiram dapat meningkatkan ketahanan tanaman tomat terhadap penyakit bercak cokelat.

Tabel 3. Masa Inkubasi, nilai AUDPC dan persentase penekanan penyakit bercak cokelat oleh berbagai perlakuan pada percobaan di tanaman tomat (pada $11 \mathrm{HSI}$ )

\begin{tabular}{lccccc}
\hline \multicolumn{1}{c}{ Perlakuan } & $\begin{array}{c}\text { Mikrob } \\
\text { Antagonis }\end{array}$ & $\begin{array}{c}\text { Masa Inkubasi } \\
\text { (HSI) }\end{array}$ & AUDPC & $\begin{array}{c}\text { Penekanan } \\
\text { Penyakit (\%) }\end{array}$ \\
\hline Kontrol & - & 5 & 49,8 & b & - \\
Pestisida & - & 5 & 48,9 & b & 1,6 \\
Isolat TJ4 & Jamur & 7 & 22,5 & a & 54,8 \\
Isolat TB6 & Khamir & 5 & 49,4 & b & 0,8 \\
Isolat TB25 & Bakteri & 6 & 30,9 & a & 37,9
\end{tabular}

Keterangan: Angka yang diikuti oleh huruf yang sama menunjukkan perlakuan yang tidak berbeda nyata pada taraf $5 \%$ menurut uji Tuckey HSD.
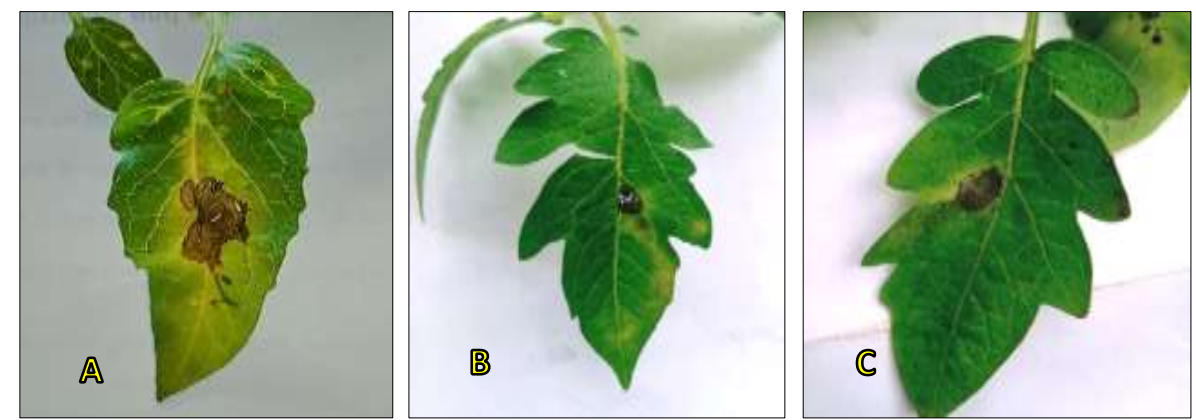

Gambar 3. Gejala penyakit bercak cokelat di daun tomat yang diinokulasi patogen pada 7 HIS. (A) Kontrol.

(B) Perlakuan dengan isolat TB25. (C) Perlakuan dengan isolat TJ4 .

Pada percobaan di tanaman tomat, isolat khamir TB6 yang pada uji in vitro dan pengujian pada buah tomat dapat menekan pertumbuhan patogen dan perkembangan infeksi pada buah, namun ternyata isolat tersebut tidak dapat menekan penyakit bercak cokelat pada daun. Hal ini kemungkinan terkait dengan kemampuan isolat untuk beradaptasi dan memperbanyak diri pada lingkungan atau habitatnya pada daun tomat. 
Pada percobaan ini, perlakuan dengan fungisida (mancozeb) ternyata tidak dapat menekan perkembangan penyakit bercak cokelat pada daun tomat. Hal ini kemungkinan karena fungisida berbahan aktif mancozeb adalah bersifat kontak sehingga akan efektif ketika patogen masih di luar jaringan tanaman atau bersifat protektan (Lodovica et al., 2010). Pada percobaan ini, jaringan tanaman yang telah dilukai dan inokulum patogen yang berupa miselia memberikan kesempatan bagi patogen untuk langsung melakukan penetrasi ke dalam jaringan tanaman, sehingga fungisida pun tidak dapat menghambat infeksi patogen yang sudah ada dalam jaringan tanaman.

Hasil penelitian secara keseluruhan menunjukkan bahwa isolat-isolat yang diperoleh dari air rendaman limbah jamur tiram hanya dua isolat yaitu satu isolat jamur (TJ4) dan satu isolat bakteri TB25 yang dapat menekan penyakit bercak cokelat pada buah tomat masing-masing sebesar $54,8 \%$ dan $37,9 \%$.

Isolat yang menunjukkan efek antagonistik yang relatif tinggi pada uji in vitro tidak selalu menunjukkan efek penekanan terhadap penyakit yang tinggi pula ketika diuji secara in vivo. Beberapa isolat pun ada yang dapat bersifat patogenik terhadap inangnya. Istifadah dkk. (2020) juga menemukan bakteri dan khamir dari air rendaman kompos yang menunjukkan efek antagonistik tinggi pada uji in vitro ternyata dapat menyebabkan pembusukan ketika diinokulasikan pada buah tomat. Hal ini menunjukkan pentingnya pengujian patogenesitas pada mikrob antagonistik hasil isolasi dari berbagai sumber. Hal ini mengingat adanya mikrob yang dapat bersifat parasit fakultatif yaitu saprofit yang dapat menjadi parasit apabila tanaman dalam kondisi lemah misalnya adanya pelukaan pada jaringan (Agrios, 2005). Dibandingkan dengan mikrob dari air rendaman bahan organik lain, mikrob yang diperoleh dari air rendaman jamur tiram ini memang tidak seefektif mikrob yang berasal dari air rendaman kompos yang dapat menekan penyakit bercak cokelat pada tanaman tomat sebesar 77,5\%-98,1\% (Istifadah dkk., 2020).

Perbedaan potensi isolat ini dapat dikarenakan bahan dasar dari bahan organiknya yang memang berbeda sehingga isolat yang diperoleh juga berbeda. Walaupun demikian, aplikasi isolat-isolat tersebut dalam bentuk konsorsium mikrob kemungkinan dapat meningkatkan efek pengendaliannya.

\section{SIMPULAN DAN SARAN}

\section{Simpulan}

Dari 23 isolat mikrob yang diisolasi dari limbah jamur tiram, delapan isolat (empat isolat jamur berhifa, satu isolat khamir dan tiga isolat bakteri) dapat menghambat pertumbuhan $A$. solani secara in vitro dengan tingkat penghambatan berkisar antara $73,4 \%-86,9 \%$. Pada pengujian di buah tomat, dua isolat jamur berhifa dari genus Rhizopus dapat menyebabkan pembusukan pada buah tomat, sementara tiga isolat non patogenik (masing-masing satu isolat jamur, bakteri dan khamir) dapat menghambat infeksi $A$. solani pada buah tomat sebesar $78,4 \%$ dan $83,7 \%$. Pada pengujian di tanaman tomat, hanya dua isolat yaitu isolat jamur TJ4 dan isolat bakteri TB25 dapat menekan penyakit bercak cokelat pada daun tomat, masing-masing sebesar $54,8 \%$ dan $37,9 \%$.

\section{Saran}

Isolat-isolat mikrob yang paling baik dalam menghambat penyakit bercak cokelat pada penelitian ini perlu diidentifikasi lebih lanjut agar diketahui genus dan spesiesnya.

\section{UCAPAN TERIMA KASIH}

Penelitian ini merupakan salah satu bagian dari serangkaian penelitian yang didanai oleh DRPM-DIKTI 2019 melalui skema "Penelitian Dasar Unggulan Perguruan Tinggi (PDUPT)". Terimakasih juga disampaikan kepada Ibu Ir. Astrid Sunarti dan Ibu Hesti dari IP Farms Lembang yang telah memberikan baglog jamur tiramnya.

\section{DAFTAR PUSTAKA}

Adedeji KO, and MOA Aduramigba. 2016. In vitro evaluation of spent mushroom compost on growth of Fusarium oxysporium f. sp. lycopersici. Advances in Plants and Agriculture Research. 4(4): 332-339.

Adhikari P, Y Oh, and DR Panthee. 2017. Current status of early blight resistance in tomato: an update. International Journal Molecular Science. 18:1-22.

Agrios, GN. 2005. Plant Pathology. Fifth Edition, Academic Press. San Diego. California.

Aslam, S, and Saifullah. 2013. Organic management of root knot nematodes in tomato with 
spent mushroom compost. Sarhad Jurnal Agriculture. 29(1): 63-69.

Chaerani, R, and RE Voorrips. 2006. Tomato early blight (Alternaria solani): the pathogen, genetics, and breeding for resistance. Journal of General Plant Pathology. 72: 335-347.

Davis, WW, and TR Stout. 1971. Disc plate method of microbiological antibiotic assay. II. Novel procedure offering improved accuracy. Applied Microbiology. 22(4): 666-670.

Dhingra, OB, and JB Sinclair. 1995. Basic Plant Pathology Methods. 2nd Edition. CRC Press. Boca Raton.

Herawati, L, dan N Istifadah. 2018. Potensi limbah media jamur tiram (Pleurotus ostreatus) dan shiitake (Lentinula edodes) untuk mengendalikan penyakit rebah semai (Rhizoctonia solani) pada tomat. Jurnal Cropsaver. 1(2): 93-97.

Istifadah, N, and L Herawati. 2019. The potential of microbes isolated from spent substrate of shiitake and oyster mushrooms to induce tomato resistance against early blight disease. International Seminar of Indonesia Microbiology Society, UNS, Surakarta.

Istifadah, N, PG Novilaressa, F Widiantini, dan S Hartati. 2020. Keefektifan bakteri dan khamir asal air rendaman kompos dalam menekan perkembangan penyakit bercak coklat (Alternaria solani Sorr.) pada tomat. Jurnal Agrikultura. 31(1): 52-60.

Köhl, J, R Kolnaar, and WJ Ravensberg. 2019. Mode of action of microbial biological control agents against plant diseases: Relevance beyond efficacy. Front. Plant Sci, 19. doi.org/10.3389/fpls.2019.00845.

Kwon, J-H, S-W Kang, J-S Kim, and CS Park. 2001. Rhizopus soft rot on cherry tomato caused by Rhizopus stolonifer in Korea. Mycobiology. 29(3): 176-178.

Lodovica, M, F Tinivella, A Garibaldi, GM. Kemmit, L Bacci, and B Sheppard. 2010. Mancozeb: Past, Present, and Future. Journal of Plant Disease, 94 (9): 1076-1087.

Madden LV, Hughes G, and F. van den Bosch. 2007. The Study of Plant Disease Epidemics. APS Press. St. Paul.

Mahmood, I, SR Imadi, K Shazadi, A Gul, and KR Hakeem. 2016. Effects of pesticides on environment. In: Pp. 254-269 Plant, Soil and Microbes. Volume 1: Implications in Crop Science (Hakeem, KR, MS Akhtar, SNA Abdullah, Eds.). Springer International. Switzerland.

Omokaro O, and AA Ogechi. 2014. Cultivation of mushroom (Pleurotus ostreatus) and the microorganisms associated with the substrate used. e-Journal of Science \& Technology. 8(4): 49-59.

Rinker, DL. 2017. Spent mushroom substrate uses. In: DC Zied and AP Giménez (Eds), Edible and Medicinal Mushrooms: Technology and Applications. John Wiley \& Sons. Pp. 427454.

Seephueak, P, C Preecha, and W Seephueak. 2017. Isolation and screening of cellulolytic fungi from spent mushroom substrates. International Journal of Agricultural Technology. 13(5):729-739.

Singh, D, and RR Sharma. 2018. Postharvest diseases of fruits and vegetables and their management. In: Pp. 1-52 Postharvest Disinfection of Fruits and Vegetables (MW Siddiqui, Ed.). Academic Press. Cambridge.

Viji, G, W Uddin, and CP Romaine. 2003. Suppression of gray leaf spot (blast) of perennial ryegrass turf by Pseudomonas Aeruginosa from spent mushroom substrate. Biological Control. 26(3): 233-243.

Wiafe-Kwagyan, M, and GT Odamtten. 2018. Use of Pleurotus eous strain P-31 spent mushroom compost (SMC) as soil conditioner on the growth and yield performance of Capsicum annuum L. and Solanum lycopersicon L. seedlings under greenhouse conditions in Ghana. Tropical Life Sciences Research. 29(1): 173-194.

Yusidah, I, and N Istifadah. 2018. The abilities of spent mushroom substrate to suppress basal rot disease (Fusarium oxysporum fsp cepae) in shallot. International Journal of Biosciences, 13 (1): 440-448.

Zulfikar, A, IN Layla, C Preecha, W Seephueak, and P Seephueak. 2018. Use of antagonistic bacteria from spent mushroom compost for controlling damping-off cause by Fusarium solani in tomato. Proceeding Series. $6^{\text {th }}$ Asian Academic Society International Conference (AASIC). Pp 630-638. 